\title{
SUPERNATURAL CHARACTERS IN THE QUASI-HISTORICAL DISCOURSE OF MODERN UKRAINIAN LITERATURE: SPECIFICITY AND FUNCTIONS
}

\begin{abstract}
The article is aimed at the study of Ukrainian quasi-historical novels of the early $21^{\text {st }}$ century, characterized by the renunciation of "objectivity" of the narrative and emphasized the role of imagination. These are the pieces by Bakalets and Yarish ("From the Seventh Bottom"), Vynnychuk ("The Pharmacist", "Lutetia"), and by Yatsenko ("Nechui. Nemov. Nebach"). The study reveals the features and functions of fantastic characters in the abovementioned novels. These fictional images of modern Ukrainian quasihistorical literary discourse are characterized by infernality, grotesque anthropomorphism, destruction of traditional antinomy "otherworldlyearthly/human", philosophical and ironic coloring. Interpreting the fantasy in quasi-historical novels is expedient in the context of the global problem of perception of historical past by people of the $21^{\text {st }}$ Century, with an emphasis on significant changes in public consciousness motivating writers to "Re-write/Reimagine the past". The spread of this phenomenon reveals public distrust of the authorities, offering "correct" answers to the questions about past events, protest against permanent manipulation of historical facts (the tendency of growing consciousness and intellectualization of society).
\end{abstract}

Keywords: quasi-historical novel; fantasy; postmodernism; intertextuality; "double coding".

Modern Ukrainian society shows great interest in national history. There is an acute necessity and strong intention to preserve our national identity as well as the basics of Ukrainian sovereignty under the hard political conditions of the day. National history, as well as the national language have become the values

\footnotetext{
* Zaporizhzhia National University, Ukraine.
} 
that are crucial for the development of our country and the prosperity of its culture.

Thus, the question of the specifics of creative representation of the past in Ukrainian literature of the $21^{\text {st }} \mathrm{C}$. deserves special attention. A general review of creative pieces by national authors allows us to distinguish the two main trends. Firstly, there is a significant number of historical novels with an emphasized reference to the "plausibility" of the depicted images (truly "historical" novels), and secondly, there is a special type of literary pieces characterized by underlined conventionality, renunciation of "claims" for objectivity and great role of fantasy ("quasi-historical" novels).

The purpose of our article is to characterize the specifics and functions of supernatural characters in the Ukrainian quasi-historical literary discourse of the early $21^{\text {st }}$ Century.

The object of the research includes a number of Ukrainian quasi-historical novels of the early 21 $1^{\text {st }}$ Century, namely by Bakalets and Yarish ("From the Seventh Bottom"), by Vynnychuk ("The Pharmacist", "Lutetia"), as well as by Yatsenko ("Nechui. Nemov. Nebach").

The topicality of our studies is defined by several factors.

Firstly, there is an urgent need for a holistic understanding of the global problem of "Re-writing/Re-imagining the past" in the art of the $21^{\text {st }}$ Century, as the relevant general conclusions (or at least reasoned hypotheses) can be made only on the basis of analysis of the concrete literary material representing different cultures. This makes modern Ukrainian literature worthy of attention in the context of this broad topic.

Secondly, the theoretical generalizations presented in our work can be used as a basis for considering similar phenomena in other national literatures.

Thirdly, the suggested observations may be of interest to proponents of comparative methodology and open up prospects for research in this direction through the comparison of similar novels by different authors in the typological aspect.

\section{Theoretical and Methodological Basis of the Study}

A lot of research by Ukrainian scholars is devoted to the study of the "historical" prose of modern Ukrainian literature, while the comprehensive coverage of quasi-historical novels in Ukrainian literary criticism can hardly be found (especially in the prose of the last decades of the $21^{\text {st }}$ Century). It is 
possible to find only some comments on certain aspects of their functioning. For example, when studying the "postmodern historical novel", Peshorda singles out "a type of fiction in which the discourse of historical novel, and often that of historiographical prose is combined with fantasy". The scholar claims that this experimental type of novel has finally acquired "the true recognition of its legitimacy within the genre system of novel varieties" (Пешорда 14) while denying its right to be considered a full-fledged historical novel.

As for the international literary critical discourse, the definitions of "pseudo-historical" novel and "quasi-historical" novel are used concurrently to characterize similar phenomena in different national cultures. The studies by Ashcheulova, "Postmodern "Pseudo-historical" Novel: Strategies of Genre Development" and Gorozdi, "The Magic of Historical Narration. On the 'PseudoHistorical' Contemporary Hungarian Novel" are noteworthy in this regard.

Recognizing the term "pseudo-historical novel", we still consider the notion of "quasi-historical novel" to be more relevant.

Firstly, the adjective "pseudo-historical" is often perceived as the one referring to "pseudo-history" in a broad sense, i.e. a phenomenon not purely artistic but a socio-political one: "Invented Knowledge: False History, Fake Science and Pseudo-Religions" (Fritze), "Pseudohistory and Pseudoscience" (Allchin), etc.

Secondly, the prefix "pseudo" ("deception", "fiction", "error", "false") indicates a full, complete denial of the veracity of the portrayed material, while the concept of absolute "truth" and "untruth" is unacceptable to the postmodern philosophical paradigm. Whereas the prefix "quasi" ( "allegedly", "apparently", "barely") is more appropriate within this study as it indicates the relativity of doubts and a certain degree of distrust of "official history", i.e. it fully satisfies purely postmodern sentiments.

The emergence of related fiction is a natural result of the popularization of postmodernist philosophy in general and its inherent concept of history in particular. It is widely known that the question of the "relationship" of postmodern culture and history is covered in detail in the works of postmodern theorists: Hutcheon "A Poetics of Postmodernism: History, Theory, Fiction" (Hutcheon 85-130), Jameson "Postmodernism, or The Cultural Logic of Late Capitalism" (Jameson 17-22), etc. Jameson points out that postmodernism reflects the past as "a multitudinous photographic simulacrum" (Jameson 18). Using Baudrillard's concept ("History is our lost referent, that is, our myth" 
(Baudrillard 46)), the researcher develops the opinion of his predecessor on the illusory essence of the concept of "historical reality".

At the same time, Berlatsky appealing to the ideas of Derrida, Lyotard, Hutcheon, underlines the following: "By identifying how various examples of postmodernist historical fiction redefine both the real and historical referentiality itself without abandoning it, I believe we can escape the most troubling repercussions of deconstructive readings of history without sacrificing the theoretical insights of poststructuralism and postmodern theory. That is, postmodernist historical fiction has much to teach us about the nature of reality itself and particularly its representation" (Berlatsky 4).

Focusing on the abovementioned theoretical positions helps in the study of quasi-historical narrative, namely, the disclosure of its nature, directly related to simulacrization, functions, and perspectives of interpretation, including the aspect of the importance of such literature for understanding the worldview basics of modern society.

However, despite the achievements in this field, there are still many gaps that necessitate scientific research based on certain national literatures to comprehensively cover the genre modifications of the $21^{\text {st }}$ Century, which testify to the desire to destroy any canons, traditions, engage in creative experiments and express relativistic "distrust" of "official" history. After all, the art of each country adds to the development and establishment of this global trend.

The research of peculiarities and the role of fictional elements in such works deserves special attention as it contributes to the formation of a complete picture of the leading "trends" in the transformation of today's fiction. We also find it interesting to consider the problem of the $21^{\text {st }}$ Century perception of the past through the prism of the fantasy of a quasi-historical novel with an emphasis on significant changes in the public consciousness that determine the desire of writers to "re-write / re-imagine the past". This underlines the practical significance of the analysis of the quasi-historical narrative.

The purpose of the study determines research methodology based on the combination of techniques of cultural-historical, comparative, and intertextual methods of analysis. The cultural-historical method allows to determine the degree of conventionality in modern writers' representation of Ukrainian historical past; the comparative method helps to highlight similar features of fantastic characters, juxtaposing the studied novels; intertextual method of analysis aims at defining the main functions of supernatural characters of 
University of Bucharest Review $\propto$ Vol. XI/2021, no. 2 (new series)

Re-writing, Re-imagining the Past (IV)

Ukrainian quasi-historical novels against the background of cultural tradition and within the spectrum of ideas and poetics of postmodernism.

The latest of these methods is also productive for characterizing the principle of "double coding" (Jencks 131), inherent in modern Ukrainian quasihistorical novels and implemented, among other things, through fiction. Kristeva's concept, formed as a result of rethinking the ideas of M. Bakhtin, J. Derrida, R. Barthes, is based on the assumption that any text is an intertext, i.e. a "space" where "elements", "components" of other texts coexist (Kristeva 400). This approach allows us to consider the quasi-historical prose of the $21^{\text {st }}$ Century through the prism of its inherent symbolic allusions and reminiscences, which ensure the orientation of fiction towards both "mass" and "elitist" recipients (a specific feature of postmodern art, characterized by R. Barthes, L. Fiedler, C. Jenks, etc.).

\section{Supernatural Characters in the Novel "From the Seventh Bottom" by Bakalets and Yarish}

Though each of the writers displays their original creative style, their novels share the same traits and namely they present a combination of concretehistorical and imaginary traits. Here supernatural, demonic, bizarre, creatures endowed with superhuman abilities act along with the famous historical figures. The events of the past that are well-known to the modern reader create the backdrop for their interaction.

For example, the novel by Bakalets and Yarish "From the Seventh Bottom" (2013) depicts the era of the Ruin (the period of Ukrainian history of the second half of the $17^{\text {th }}$ Century, marked by the escalation of social conflicts, bloody wars, general decline). In the book, one can see well-known historical figures (Vyhovsky, Briukhovetsky, Bohun, Somko who were Ukrainian hetmans, i.e. elected leaders of Ukrainian / Cossack troops, military leaders). At the same time, different infernal creatures also fight for power, namely devils, witches, ghouls, lisovyk (a forester, the spirit of the forest), mana (a ghost), poliovyk (the spirit of the fields), vodianyk (waterman, a spirit living in ponds), vovkulaka (werewolf) and other characters of Ukrainian folk demonology. The narrator himself is a demon named Nedoliya, who tells about the terrible pages of Ukrainian history and his role in the political intrigues of the time.

The image of a humanized devil in the novel by Bakalets and Yarish is especially interesting because it is belittled, devoid of the aura of "demonic 
greatness". First, Nedoliya uses the human body as a kind of disguise, and later he gradually starts to feel and think like a man (falls in love, dreams of home comfort). "Without realizing it, I began to turn into a man! I wanted the comfort of home, I grew fond of my work, I even wanted to have a child," (Бакалець та Яріш 264) says the infernal creature.

In the studied novel there is a strong reference to Dante's "Divine Comedy", as well as to the traditional plots of literary demonology, representing the love relationship between a supernatural creature and a human being.

For example, in the preface to the novel the authors underline that the title of their piece is an intertextual one, designed for the knowledgeable reader who is familiar with the work of Dante: "According to Dante, the seventh circle of hell is for suicides. There are many of them in the history of Ukraine. By destroying their souls for the sake of earthly things, they have repeatedly threatened the country with destruction." (Бакалець та Яріш 6). The basic dissimilarity here is that Dante's protagonist goes on a journey through hell himself, while in the novel by Bakalets and Yarish the situation is different because in this story devils, inhabitants of hell, travel through Ukrainian lands, watching the lives of sinners who are ready to commit any crime to obtain power. The story about hell told by Nedoliya, the fiend, proves that customs in the afterlife are very much like earthly ones (there are slanders, envy, careerism, etc.).

The love story in the novel is also interesting as the devil in love is ready to break with the world of evil for the sake of his chosen one, to start a new life. This narrative evokes associations with various works of art: "The Devil in Love" (1772) by the French writer Cazotte, novels of Russian literature e.g. "Demon" by Lermontov, "Diary of Satan" by Andreiev, "Altist Danilov" by Orlov, etc. All these works depict an infernal creature in love with a human being and very often represent their desire to turn to the side of the Good to maintain such a relationship.

Thus, the quasi-historical novel by Bakalets and Yarish is an intertext endowed with the elements of other texts and a connection with the cultural tradition.

Substantiating their creative experiments in the field of historical prose, the authors of the novel "From the Seventh Bottom" note the following: "Of course, the presence of mysticism and fantastic-mythological elements does not allow to classify this work as a piece of once very respectable genre of the historical novel, or rather a historical-ideological one.... In order not to linger anymore with the 
definition of the genre, we will call the novel ... a historical fantasy, where wellknown historical events are slightly modified by imagination." (Бакалець та Яріш 6).

However, the authors do not just allow themselves a "minor game of imagination", because the creative representation and interpretation of history in the novel refute the premise of authenticity. All the political events of the past are explained by the interference of otherworldly creatures: one can see not images but rather simulacra, a play on meanings, a fascinating story with elements of "horror" attractive to the mass audience, and at the same time an intellectual quest designed for the reader well aware of traditions of literary demonology ("double coding").

The studied novel makes us think not only about the issues of the past, but also the present dilemmas: an analogy drawn between the era of the Ruin and the $21^{\text {st }}$ Century proves that human sins are always the same.

\section{Otherworldly Creatures as Characters in the Novels by Vynnychuk ("The Pharmacist", "Lutetia")}

In the novel by Vynnychuk "The Pharmacist" (2015) the events also unfold in the 17th Century (1646-1648), first in the Venetian Republic, and then in Lviv (now a Ukrainian city).

An important role here is again played not by historical, but by demonic characters: the devil in the image of an attractive young man Franz stays among people and forms a strong friendship with the witch named Vivdia: "a skinny, slender young master dressed in German fashion came into the house ... - Ah, it's you, rascal - the witch recognized the familiar devil, who hadn't visited her for a long time" (Винничук 55).

The images of the devil and the witch create an allusion to numerous texts of "cultural demonology" which turn the novel into an intertext. This aspect was studied in detail in our article "Pseudomorphic Characters of the Novel "The Pharmacist" by Yuriy Vynnychuk in the Context of Cultural Tradition (Culturological Facets of Analysis)" (Nikolova and Vasylyna).

For example, the scene of a banquet arranged by Franz and Vivdia evokes associations with "The Night Before Christmas" by M. Gogol (Nikolova and Vasylyna 146).

The motive of a person's agreement with the devil (because the fiend in the novel is formally a servant of the alchemist Kalkbrenner) allows us to draw 
parallels with the fiction of the $18^{\text {th }}-20^{\text {th }}$ Centuries: "here it is necessary to mention J. W. Goethe ("Faust"), J. Cazotte ("The Devil in Love"), A. von Chamisso ("Peter Schlemihl's Miraculous Story"), V. Hauff ("The Cold Heart"), M. Gogol ("Evening on the Eve of Ivan Kupala"), M. Zagoskin ("The Tempter"), L. Andreev ("Diary of Satan"), J. Krus ("Timm Thaler, or the Traded Laughter"), M. Bulgakov ("The Master and Margarita"), etc." (Nikolova and Vasylyna 146).

Infernal creatures in the novel by Vynnychuk as well as in the piece by Bakalets and Yarish are as human-like as possible, the scenes with their participation have a comic rather than an appalling emotional coloring: the devil and the witch come together to drink horilka (the national Ukrainian alcoholic drink), to eat lard (a vital ingredient of Ukrainian cuisine), Franz likes to laugh at sermons in church and is generally speaking a joker and a rogue.

The images of demonic characters in this piece of prose perform a twofold function: they sharpen the plot structure to hold the attention of the mass reader and encourage serious reflection as well as unraveling of literary riddles that are important for the intellectual reader, thus creating the "double coding" in this postmodernist novel.

In "Lutetia" (2017), another work by Vynnychuk, there are two plot lines that intersect: the first one is related to the depiction of love adventures of the famous Ukrainian writer of the $19^{\text {th }}$ Century Ivan Vahylevych, and the second line represents the life of the author himself (his youth that coincides with the last twenty years of the $20^{\text {th }}$ Century). The novel has an erotic coloring and is also full of detailed descriptions of the realities of the past. The historical atmosphere of the 1880s, as well as that of the Soviet times, when the talented young man Yurko suffocates from the inability to express himself in full are depicted very realistically. The author credibly shows how difficult the fate of a creator was in the Soviet era when it was necessary to compromise with the authorities.

The point of convergence between the two historical epochs is the superreality and namely the dreams, seen by both protagonists (by Vahylevych and Vynnychuk); the mystical atmosphere is combined with the strive for plausibility in the interpretation of the phenomena of the past. Fantasy fits organically into the context of the art world of the novel, evoking associations with Dante's Divine Comedy and various myths of the peoples of the world about beast-men (intertextual function).

As for the references to Dante's text the most vivid are the following ones: the motif of the author's dream-journey to the afterlife and the ideal image of 
Lutetia-Beatrice, who accompanies him in the journey. Like Beatrice who leads Dante through the spheres of Heavens, the red-haired girl named Lutetia becomes the guide of the hero from the modern novel in the imaginary world of his dreams. She helps him to find the reasons to live for and ideals to strive for.

As for the references to the myths one should mention the story of terrible monsters that threaten the world. The struggle is on between the forces of Good and Evil in eternity. The bizarre monstrous creatures, born of human contact with animals, birds, and reptiles, want to take power over the whole world by misleading everyone. The existence of such myths in the folklore of different nations is acknowledged by the characters of the novel, who are well aware of national and world culture. For example, when Yurko talks to his girlfriend, he says: "Therefore, as you can see, the myths and legends of primitive peoples prevail here. Among them are many myths about how - here I no longer looked away from her - how people and animals lived one life. Women lived with crows, seals, deer, bears, while men lived with waterfowl and snakes. Because the feminine is always connected with the earth and water, while the masculine is connected with the sky. Water and fire, like the Tree of life, are mediators between the two." (Винничук 119)

The beast-men disguise themselves as ordinary people to destroy all living things and the Good as such, at the same time the characters of the novel believe in the victory of good forces and they are certain that world harmony can be maintained.

Thus, the quasi-historical fiction by Vynnychuk is a vivid example of "Rewriting/Re-imagining the past" in a postmodernist way within the relativistic concept of history, intertextuality, "double coding", simulacrization, etc. The philosophical aspect of the pieces of literature is aimed at comprehending the connection between the past and the present.

\section{Fantastic Characters in Yatsenko's Novel "Nechui. Nemov. Nebach"}

Yatsenko's novel "Nechui. Nemov. Nebach"(2017) depicts the events of the late $19^{\text {th }}$ - early $20^{\text {th }}$ Centuries in Ukraine; the main characters are Ukrainian cultural figures (writers Ivan Nechuy-Levytsky, Panteleimon Kulish, Taras Shevchenko, etc.) along with fictional creatures. The latter are Galician "opyrs" (vampires), i.e. ghouls from Galicia (the historical name of the Ukrainian ethnic lands, the historical region of Ukraine and south-eastern Poland), as well as Immortal Players. 
On the one hand, the historical atmosphere of the past is represented quite accurately in the book. Yatsenko's novel portrays the persecution of the Ukrainian language (in particular, the situation in educational institutions of the $19^{\text {th }}$ Century, when it was forbidden to speak Ukrainian), mentions the Black Hundreds (Russian monarchical and ultranationalist organizations that emerged after 1905 in the Russian Empire, had their fighting "squads" who staged massacre of the Jews in Ukraine). It also shows the difficult struggle of Ukrainian writers for national cultural values.

On the other hand, the feeling of the probability of the events destroys the fantastic element. The imaginary characters of Yatsenko's quasi-historical novel, as well as the heroes of the works by Bakalets, Yarish, and Vynnychuk, are very similar to ordinary people.

Upyrs (fictional bloodsucking beasts, vampires) are humanized to the extreme and become an organic part of the human world. They are not horrible creatures with fangs, but ordinary men in crumpled jackets, with thin hair and red fleshy faces, they look like tradesmen (Яценко 20). They spend their time drinking, playing cards, indulge in idle chatting and complaining about the new times because they are "not very smart in politics" (Яценко 62).

The three Immortal Players (from the West, East and North) are supernatural creatures who control the course of history (the concept of history as a result of the "play" of the Higher Powers). These are real gentlemen, they are well dressed and are perceived as very wealthy men (Яценко 39).

"Nechui. Nemov. Nebach" is an intertextual novel that actualizes different associations in the mind of a knowledgeable recipient. For example, the images of the three Immortal Players can be interpreted as an allusion to the three Magi, and such an eloquent artistic detail as the handle of Western master's cane in a form of an animal's head alludes to the cane of another demonic character, namely to Woland from Bulgakov's "The Master and Margarita".

Yatsenko's piece is a good example of Ukrainian quasi-historical novels of the $21^{\text {st }}$ Century, combining history and fiction, destroying the tendency towards "objectivity" and "probability".

\section{How? What for? Why?}

To sum up, it is necessary to note that the appearance of supernatural creatures as characters in quasi-historical prose is a distinctive feature of modern Ukrainian literature. The comparative analysis gives grounds to affirm such 
University of Bucharest Review $\propto$ Vol. XI/2021, no. 2 (new series)

Re-writing, Re-imagining the Past (IV)

images' similarity, the existence of a certain specific tendency connected with "rewriting" of the Ukrainian history by modern authors.

The common features of the fantastic characters of the quasi-historical narrative are as follows.

1) They are mostly demonic, infernal beings, the ones that, according to the traditional concept, embody evil, pose threat to people. This is due to the desire to satisfy the tastes of the mass audience, eager for "horror", as well as to "shift responsibility" for the terrible, tragic events, plentiful in Ukrainian history, onto the dark forces.

2) The studied images are anthropomorphic: their humanization often acquires grotesque forms, reaching to the absurd. Despite their belonging to the supernatural world, they look, behave, think and feel like people or rather they skilfully pretend to be human. Such a transformation is fully in line with the postmodernist approach to the destruction of any hierarchical systems, traditions, and patterns: it is an ironic game on the level of deconstruction of the constant opposition "otherworldly - earthly/human".

3) The characters are allusions to various texts of world culture, folklore, myths. Giving them such significance contributes to the creation of an intertextual space, helps to evoke the interest of an elite, "informed" audience.

4) The images have a philosophical colouring, encourage serious reflection, they are driving forces of the historical process, a link between past and present. This also meets the needs of the intellectual audience.

The main functions of the fantastic characters of the quasi-historical novel are the following.

1) Conscious ruining "expectations" as for the traditional narrative and the canon of historical prose, simulacrization, and expression of "distrust" towards the "objective" fact of the past, artistic representation of relativistic doubts are in tune with the postmodern principles. It seems as if the author wants to tell the readers: "Yes, it's incredible. But who can unequivocally state that the "official" canonized version of events is plausible and true?"

2) Creating intertextual connections and "double coding" (fascinating history, necessary for a mass audience along with subtext, philosophical meaning, allusions to literary works from a broad cultural context, designed for the intellectual reader). 
3) Involving the recipient in an ironic play on meanings, creating a general sense of the chaotic, illusory, and fanciful world that is immanent to postmodernist consciousness.

The strong appeal of supernatural characters testifies to the existence of a powerful tendency, which exemplifies a kind of "fatigue" of society from the authorities, who persistently impose "correct answers", "absolute truth" on it. This is a kind of revolt against discredited values, the constant manipulation of facts in favour of the dominant financial and political interests, the mechanisms of which become too obvious due to information technology of the late $20^{\text {th }}$-early $21^{\text {st }}$ Century. Writers seem to engage in creative experiments to say: "If they can do that, then why can't we do the same?" This aspect is essential evidence of the growth of consciousness and intellectualization of society.

The combination of fiction and "history" can be interpreted as a manifestation of some sort of social "infantilism". This renunciation of responsibility for the past, the course of events that is shifted onto fantastic creatures, the desire for a simplified perception of ambiguous facts, creating the cult of the game modus reveal the opposite side of postmodern relativism.

\section{Conclusions}

Thus, the characteristic features of modern "quasi-historical" novels are the conscious rejection of "claims" for "credibility" and emphasis on fantasy and fiction. In Ukrainian literature these tendencies are exemplified by the novels of the early 21 ${ }^{\text {st }}$ Century, namely by Bakalets and Yarysh's "From the Seventh Bottom", Vynnychuk's "The Pharmacist" and "Lutetia", Yatsenko's "Nechui. Nemov. Nebach". Their popularity is a natural consequence of active dissemination of the philosophy of postmodernism in general and its inherent concept of history in particular (relativism, distrust of the "official" versions of the past, simulacrization, ironic modus, cult of the text, destruction of traditions, "combination of incompatible", etc.).

The specificity of the fantastic characters in the quasi-historical narrative is defined by the fact that these images are demonic, traditionally perceived as hostile to people; grotesque, anthropomorphic as a result of the deconstruction of the opposition "otherworldly - earthly/human"; they create allusions to various texts of world culture, folklore, myths and acquire a philosophical and ironic coloring. 
University of Bucharest Review $\propto$ Vol. XI/2021, no. 2 (new series)

Re-writing, Re-imagining the Past (IV)

Their functions are as follows: the destruction of the genre canons of the historical novel, simulacrization and questioning the "objectivity" of history; creation of intertext and "double coding" (where "horror" is for the mass recipient, philosophical subtext, and intertextual riddles are for the intellectual reader); ironic play on meanings, creating a general sense of the chaotic and illusory world which is immanent to postmodernist consciousness.

The study of the fictional elements of the quasi-historical novel can contribute to the understanding of ideas about history by our contemporaries. The attractiveness of this phenomenon designates, on the one hand, public distrust of the authorities, who offer the audience unambiguous, "correct" answers to questions about past events, their rebellion against permanent manipulation of historical facts (the tendency of rising consciousness and intellectualization of society). On the other hand, it shows a subconscious desire to get rid of responsibility for the course of history (which is moved onto fantastic creatures, the "Higher Powers" that are not subject to people), the primitivization of complex, ambiguous facts, the cult of the game (social "infantilism").

Our research contributes to a holistic, comprehensive understanding of the processes of "Re-writing/Re-imagining the past" and creates a theoretical basis for the consideration of such phenomena in different national cultures, opens up the prospects of comparative analysis in the typological aspect.

\section{Works Cited}

Allchin, Douglas. "Pseudohistory and Pseudoscience." Science E Education, vol. 13, 2004: 179-95.

Baudrillard, Jean. Simulacra and Simulation. Editions Galilee, 1981, 0ducks.files.wordpress.com/2014/12/simulacra-and-simulation-by-jeanbaudrillard.pdf.

Berlatsky, Eric L. Fact, Fiction, and Fabrication: History, Narrative, and the Postmodern Real from Woolf to Rushdie. 2003. The University of Maryland. Ph. D.Thesis.

Fritze, Ronald H. Invented Knowledge: False History, Fake Science and PseudoReligions. London, Reaktion Books, 2009.

Gorozdi, Judit. "The Magic of Historical Narration. On the 'Pseudo-Historical' Contemporary Hungarian Novel." World Literature Studies, vol. 8, no. 2, 
University of Bucharest Review $\propto$ Vol. XI/2021, no. 2 (new series)

Re-writing, Re-imagining the Past (IV)

2016: 50-63.

Hutcheon, Linda. A Poetics of Postmodernism: History, Theory, Fiction. New York, Routledge, 1988.

Jameson, Fredric. Postmodernism, or The Cultural Logic of Late Capitalism. Durham, Duke University Press, 1991.

Jencks, Charles. "13 Propositions of Post Modern Architecture." Theories and Manifestoes of Contemporary Architecture, 1997: 131-2.

Nikolova, Oleksandra, and Kateryna Vasylyna. "Pseudomorphic Characters of the Novel 'The Pharmacist' by Yuriy Vynnychuk in the Context of Cultural Tradition (Culturological Facets of Analysis)." Modern Philology: Promising and Priority Areas for Scientific Researches: Collective Monograph, Lviv-Torun, Liha-Pres, 2020: 132-158.

Ащеулова, Ирина. "Постмодернистский «псевдоисторический» роман: стратегии жанрового развития." Дергачевские чтения - 2006. Русская литература: национальное развитие и региональные особенности : материаль международной научной конференциии, Екатеринбург, 5-7 октября 2006 2. [Ashcheulova, Irina. "Postmodernistskiy "psevdoistoricheskiy» roman: strategii zhanrovogo razvitiya." Dergachevskiye chteniya - 2006. Russkaya literatura: natsional'noye razvitiye $i$ regional'nyye osobennosti : materialy mezhdunarodnoy nauchnoy konferentsii, Yekaterinburg, 5-7 oktyabrya 2006; "Postmodern "Pseudo-Historical" Novel: Strategies for Genre Development." Dergachev Readings - 2006. Russian Literature: National Development and Regional Features: Proceedings of an International Scientific Conference, Yekaterinburg, October 5-7, 2006], vol. 2, 2007: 15-24.

Бакалець, Ярослава та Ярослав Яріш. Із сьомого дна. [Bakalets, Yaroslava and Yaroslav Yarish, Iz siomoho dna; From the Seventh Bottom]. Kharkiv: Klub Simeinoho Dozvillia, 2011.

Винничук, Юрій. Anтекар [Vynnychuk, Yuri. Aptekar; The Pharmacist]. Kharkiv: Folio, 2015.

---. Aютеція [Vynnychuk, Yuri. Lutetia]. Kharkiv: Folio, 2017.

Кристева, Юлия. “Текст романа.” Избранные труды: Разрушение поэтики [Kristeva, Yulia. "Tekst Romana." Izbrannyye trudy: Razrusheniye poetiki; "Text of the Novel." Selected Works: The Destruction of Poetics], Moscow, ROSSPEN, 2004: 395-593.

Пешорда, Дамір. Жанрові модифікації сучасного історичного роману. 2001. 
Автореферат дисертації на здобуття наукового ступеня кандидата філологічних наук [Peshorda, Damir. Zhanrovi modyfikatsiyi suchasnoho istorychnoho romanu. 2001. Avtoreferat dysertatsiyi na zdobuttya naukovoho stupenya kandydata filolohichnykh nauk; Genre Modifications of the Modern Historical Novel. 2001. Abstract of the dissertation for the degree of Candidate of Philological Sciences]. Lviv.

Яценко, Петро. Нечуй. Немов. Небач [Yatsenko, Petro. Nechui. Nemov. Nebach]. Yatsenko. Lviv, LA "Piramida", 2017. 